\title{
Antiseptic polymer materials
}

\author{
(C) Ilgiz Kh. Garaev, ${ }^{1}$ Ildar N. Musin, ${ }^{1}$ and Lyubov A. Zenitova ${ }^{2} *^{+}$ \\ ${ }^{1}$ Department of Medical Engineering; ${ }^{2}$ Department of Synthetic Rubber. Kazan National Research \\ Technological University. K. Marx St., 68. Kazan, 420015. Republic of Tatarstan. Russia.
} Phone: (843) 231-43-83.E-mail: imusin@kstu.ru

\begin{abstract}
*Supervising author; ${ }^{+}$Corresponding author
Keywords: antiseptic, polymer, composition, synthesis, processing.

Abstract

The work is devoted to the analysis of information in the domestic and foreign literature on antiseptic polymer materials. Recently, there has been an increased interest in polymeric materials (compositions), which, in addition to the properties inherent in polymeric materials (a combination of elasticity and strength, corrosion and chemical resistance, etc.), have antiseptic properties, i.e. when the polymer exhibits its antimicrobial properties in contact with the polymer surface. The manifestation of antiseptic properties of polymers is possible in the presence of active atoms or groups with antimicrobial properties in the polymer chain itself, as well as in the presence of antimicrobial substances in the composite material as an additional additive. Both methods of creating antiseptic polymer systems are described in the scientific literature. In terms of the volume of messages, the composite (second) method for creating antiseptic polymer composite materials significantly exceeds the synthetic (first) method, since it is simpler and more accessible, both in terms of technology and the availability of components for their creation. Various classes of compounds with antiseptic properties are considered as potential components of antiseptic polymer compositions. The existing terminology used in the field of antiseptic systems is analyzed.
\end{abstract}

\section{References}

[1] L.A. Blatun. Modern iodophors - effective drugs for the prevention and treatment of infectious complications. Consilium medicum. 2005. Vol.7. No.1. P.83-85. (russian)

[2] V.V. Mikhalsky, S.V. Goryunov, A.E. Bogdanov et al. Use of Betadine in the treatment of infected wounds. Russian Medical Journal. Surgery. Urology. 2010. Vol.18. No.29. P.1780-1788. (russian)

[3] S. Langer, M. Sedigh Salakdeh et al. The impact of topical antiseptics on skin microcirculation. Eur J Med Res. 2004. Vol.9. No.9. P.449-54.

[4] N. Majidipour, Z. Abdeyazdan, A. Zargham-Boroujeni. Iran J Nurs Midwifery Chlorhexidine orpovidone-iodine:Which solution is more effective on skin colonization in neonates? Iranian $J$ of nursing and midwifery research. 2013. Vol.18. No.1. P.54-58.

[5] J.C. Dumville, E. Mc Farlane, P. Edwards, A. Lipp, A. Holmes. Preoperative skin antiseptics for preventing surgical wound infections after clean surgery. The Cochrane database of systematic reviews. 2013. Vol.28. P.3.

[6] A.G. Smyth, G.J. Knepil. Prophylactic antibiotics and surgery for primary clefts. Br J Oral Maxillofac Surg. 2008. Vol.46. P.107-109.

[7] Effect of chlorine-containing disinfectants on the properties of PVC linoleum for medical institutions. D.F. Sadykov [and others]. Bulletin of Kazan Technological University. 2017. Vol.20. No.22. P.51-53. (russian)

[8] Braido I.S. History of antiseptics and asepsis in Russia. Leningrad: Medgiz, Leningrad. Department. 1956. 195p. (russian)

[9] D. Makunin. Microbes. Their names. Science and life. 2008. No.2. P.125-127. (russian)

[10] L.A. Blatun. Modern iodophors are effective drugs for the prevention and treatment of wounds. Local drug treatment of wounds - new domestic technologies. Almanac of the Institute of Surgery. A.V. Vishnevsky. 2009. Vol.4. No.2. P.11-14. (russian)

[11] E.F. Finnerty, D.W. Folan. Changing antibacterial sensitivities of bacterial skin diseases: office practice. 1978. Vol.23. P.227-230.

[12] S. Kraus et al. Comparison of a new formulation of mupirocin calcium with oral cephalexin in the treatment of secondarily infected traumatic lesions (SITL). Proceedings of 37 th ICAAC. 1997. Toronto, Canada. P.907-911. 
[13] B.A. Rosenberg, V.I. Irzhak, N.S. Enikolopyan. Interchain exchange in polymers. Moscow: Chemistry. 1975. 240p. (russian)

[14] D.V. Van Krevelen. Properties and chemical structure of polymers. Moscow: Chemistry. 1978. 414p. (russian)

[15] Encyclopedia of polymers: in 3 tons. Moscow: Soviet Encyclopedia. 1972. Vol.1. P.227-231. (russian)

[16] A.P. Pisarenko, Z.Ya. Havin. The course of organic chemistry. Moscow, High School. 1975. 510p. (russian)

[17] A.P. Nechaev. Organic chemistry. Moscow, High School. 1976. 288p. (russian)

[18] A.I. Artemenko. Organic chemistry. Moscow, High School. 2000. 536p. (russian)

[19] B.D. Berezin, D.B. Berezin. The course of modern organic chemistry. Moscow, High School. 1999. 768 p. (russian)

[20] A.M. Kim. Organic chemistry. Novosibirsk, Siberian University Publishing House. 2002. 972p. (russian)

[21] K. Tinius. Plasticizers, trans. with him. Moscow-Leningrad: Chemistry. 1964. 916p. (russian)

[22] Handbook of rubber. Rubber production materials. Moscow: Chemistry. 1971. 608p. (russian)

[23] X. Zveyfel. Additives to polymers. Handbook, trans. from English 6th ed. by ed. V.B. Uzdensky, A.O. Grigorov. Publishing house Infra-Engineering. 2011. 1144p. (russian)

[24] A.E. Zaikin, M.F. Galikhanov. Basics of creating polymer composite materials. Kazan, KSTU. 2001. 140p. (russian)

[25] Fillers for polymer composite materials (reference book). ed. G.S. Kac and D.V. Milevski. Moscow: Chemistry. 1981. 736p. (russian)

[26] Strengthening elastomers. ed. J. Kraus. Moscow: Chemistry. 1968. 482p. (russian)

[27] M.E. Rosenberg. Polymers based on vinyl acetate. Leningrad: Chemistry, Leningr. Separation. 1983. 175p. (russian)

[28] Encyclopedia of Polymers. Moscow. 1972. Vol.1. P.227-231. (russian)

[29] RF patent 22664337. Antiseptic polymeric material and products from it. Dobish S.V., Pelekhaty M.M., Pelekhataya O.A., Volkov A.A. Application 08.13.2008, publication 27.01.2009.

[30] H. Ivan Meléndez-Ortiz, Gustavo H.S. Varca, Ademar B. Lugao, Elemos Bucio. Intellectual polymers and coatings produced by ionizing radiation: synthesis and biomedical applications. Open Journal of Polymer Chemistry. 2015. Vol.5 No.3. P.17-33.

[31] I.Kh. Garaev, I.N. Musin. Antiseptic paints and varnishes. Bulletin of Kazan Technological University. 2018. Vol.21. No.10. P.63-66. (russian)

[32] GOST R ISO 20776-1-2010. Clinical laboratory tests and in vitro diagnostic test systems. A study of the sensitivity of infectious agents and an assessment of the functional characteristics of products for the study of sensitivity to antimicrobial agents. Part 1 . Reference method of laboratory research of the activity of antimicrobial agents against fast-growing aerobic bacteria that cause infectious diseases. Enter 01. 03. 2012. Moscow: Standardinform. 2012. 23p. (russian)

[33] Wei Ren, Weiren Cheng, Guan Wang, Ye Liu. Developments in Antimicrobial Polymers. Journal of polymer science, part a: polymer chemistry. 2017. Vol.55. P.632-639. 